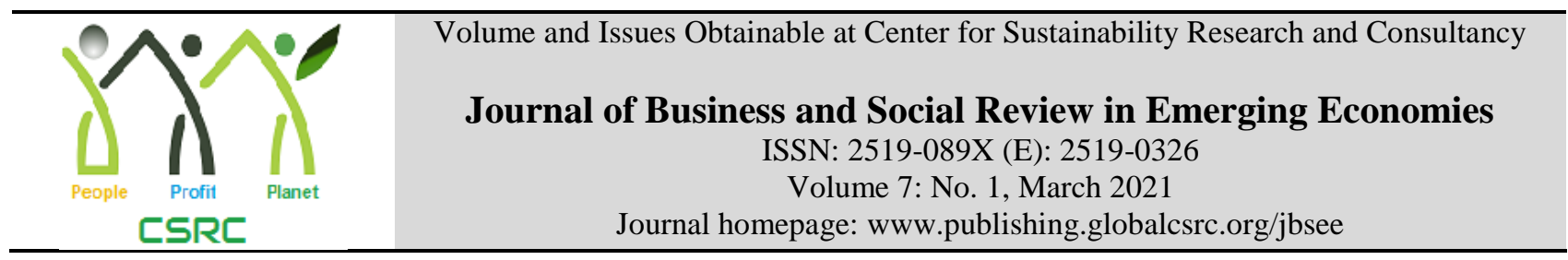

\title{
Evaluation of Climate of Selected Sixty-six Countries using Grey Relational Analysis: Focus on Pakistan
}

\begin{abstract}
*Abdul Aziz Khan Niazi, Institute of Business and Management, University of Engineering and Technology, Lahore, Pakistan

Tehmina Fiaz Qazi, Hailey College of Banking and Finance, University of the Punjab, Lahore, Pakistan
\end{abstract}

Abdul Basit, Lahore Institute of Science \& Technology, Lahore, Pakistan

Muhammad Zeeshan Shaukat, University of Central Punjab, Lahore Pakistan

*Corresponding author's email address: azizniazi@uet.edu.pk

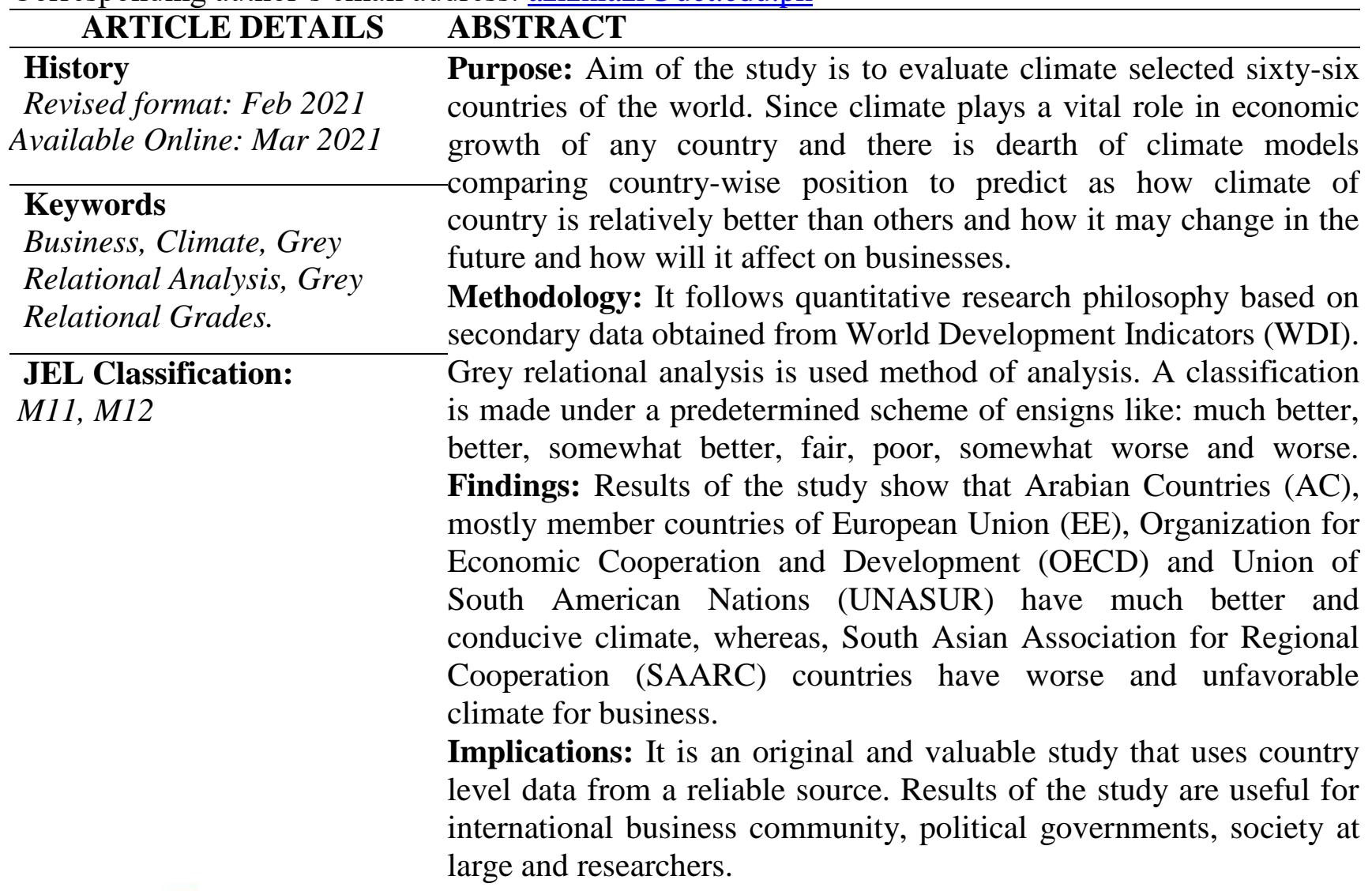

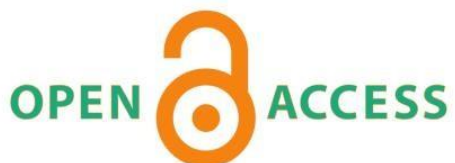

(C) 2021 The authors, under a Creative Commons AttributionNonCommercial 4.0

Recommended citation: Niazi, A. A. K., Qazi, T. F., Basit, A. \& Shaukat, M. Z. (2021). Evaluation of Climate of Selected Sixty-six Countries using Grey Relational Analysis: Focus on Pakistan. Journal of Business and Social Review in Emerging Economies, 7(1), 95-106. 


\section{Introduction}

Climate of a country has direct significant effect on day-to-day activities of business community. Tropical and climatic conditions distinguish the countries from within their competitors. Governments are inclined to predict changes in climate of the country to articulate their response by appropriate policy making. Scientists have developed quite a number of climatic models for assessment and prediction of climate. They use these models to identify that how the climate will affect the business processes. There are numerous research studies on the development of qualitative and quantitative models and the related dimensions of climate. Theoretical foundation of research and climate can be traced back from within the literature of environmental sciences. The literature is tilted towards pure sciences. Relating climate to business activities is relatively new phenomenon. There are many studies that have profound effect on different dimensions of research on climate with reference to businesses. Published research is evident on climate change across the globe including but not limited to the studies viz: climate vulnerability in urban region of Italy (Apreda et al., 2019), climate change effects on African countries' economic development (Baarsch et al., 2020), long terms impact of climate change on European forest ecosystems (de Vries et al., 2017), cascading impacts of climate change and its implications in New Zealand (Lawrence et al., 2020), impact of climate change on agriculture value chains of Nigeria (LiverpoolTasie et al., 2020), potential regional impacts from global climate change in Republic of Korea (Kim \& Lee, 2020), impact of climate change on the American lobster (Klymasz-Swartz et al., 2019), impact of climate change on tourism and hospitality sector of Cambodia (Ngin et al., 2020), climate change research in Asia Pacific (Uchiyama et al., 2020). Abid et al. (2016); Abid et al. (2019) and Aslam et al. (2018) carried a comprehensive study on climate related risks perception and adaptation in different districts of Punjab province of Pakistan and highlighted several causes like limited water availability, poverty, extreme temperature, insect attacks, water shortage \& resources, food security, crop pests and weak administration in providing proper infrastructure. Hussain et al., (2018) asserted that adaptation and mitigation in climate in relation to global context is inevitable for Pakistan. Shahzad and Abdulai (2020) found that, access to extension services and education encourages farms households to adopt climate-smart farm practices in retort to extreme weather condition that significantly reduces farmers' exposure to downside risk and net returns. Pakistan has distinctive natural climate that can support its economy and there is swear need of analysis and investigation or evaluation against the other countries. Objectives of this study include evaluation of climate of sixty six different countries. It has specially focused position of Pakistan as against rest of the countries. The study also aims to rank the countries on the basis of composite indices of grey relational grades. We have considered a wide range of methodologies for investigating the climate. The most appropriate methodology is grey relational analysis; therefore, this study uses the same. Rest of the paper is arranged as literature review, methodology, results \& discussions, and conclusion.

\section{Literature Review}

We have explored renowned research data bases like Emerald, Elsevier (ScienceDirect), WileyBlackwell, Springer and Taylor \& Francis for finding literature to set the outset of the issue and found lot of studies. Busby et al. (2018) examined eleven countries of South and Southeast Asia and proclaimed that Asian countries have the highest climate vulnerability. The proposed model i.e. Asian Climate Security Vulnerability Model - Version 1 (ACSV-V1) further documented that some areas of western \& southern Myanmar, Bangladesh, northwest and southern Pakistan are more likely to have climate change vulnerability. Hedlund et al. (2018) concluded that though climate changes emerge within the boundaries of the country and are strongly correlated with geography and economic growth. It gives a far more nuanced picture of global vulnerability that cannot adequately be clarified by either geography or economic growth alone. Hori and Syugyo (2020) argued that despite of presence of Task Force on Climate-related Financial Disclosures (TCFD) framework, it does not have clear guidelines and strict enforcement measures. Kim and Lee (2020) stated that fifty-two occupations are likely to be vulnerable occupations (including laborers working in mining industries, metal, construction, welding and machine operators) due to global climate change. Singh et al. (2019) reported devastating impact of climate change on marine ecosystems which need to be addressed to attain sustainable development 
goals.

\section{Literature on Climate in Context of Pakistan}

It is pertinent to document efforts made by researchers in sphere of climate change in Pakistan. Batool \& Saeed (2018) analyzed climate risks and vulnerability faced by cotton farmers in Pakistan. Ahmed et al. (2016) assessed climate change and possible damages in agriculture sector of Pakistan and revealed disproportionate impacts on fisheries, livestock and crops. Ali and Erenstein (2017) buttressed that educated and young farmers are more likely to use of draught tolerant varieties, shifting to new crops and sowing time adjustment as compare to 'farmers having joint families, farm more land and are wealthier'. Fahad et al. (2020) gathered data from 400 farm household from Khyber Pakhtunkhawa province of Pakistan and claimed that $73 \%$ farm households are well aware of climate change. Their study further highlighted that demographic and socioeconomic factors (education level, land ownership status, farm household age, access to data sources and farming experience) impact on households' awareness level. Javid et al. (2019) bi-furcated Pakistan into five classes (humidity, drought, cold drought, aridity and wetlands) on the basis of remote sensing and a new climatic compound index to measure humidity, aridity and semi-aridity. Khan et al. (2016) analyzed the current and future potential effect of climate change in Pakistan and stressed on national plans and policies to examine the degree to which climate related problems have been incorporated into them. Malik et al. (2012) revealed that Balochistan is the most vulnerable area followed by Punjab; threats faced by each of these regions depend on the type of climate change. Nasim et al. (2018) and Amin et al. (2018) predicted future risk by assessing heat wave trends, precipitation and temperature in different provinces of Pakistan using SimCLIM model (statistical downscaling model use for trend projections). Saeed and Athar (2018) conducted a comprehensive study to assess the spatio-temporal of 2 basic climatic parameters i.e. precipitation and temperature in Pakistan using IPCC AR4 (Intergovernmental Panel on Climate Change Fourth Assess Report) based on AOGCMs (Atmospheric Ocean General Circulation Models). Salik et al. (2015) bolstered that coastal communities are not only vulnerable to, but also sensitive to climate change threats. The results further indicated that low levels of education, insufficient diversification of income and lack of access to basic services have a detrimental effect on the adaptive potential of the entire local population. Ullah et al. (2018) collected data from 279 household of Swat district of Pakistan and stated that people of this region perceive a substantial climate change as compare to previous years.

\section{Theoretical Framework}

Theoretical framework decides limits of the study. It is important to maintain balance in brevity and comprehensiveness of a study. We have followed the framework from WDI 2020. The variable specification, description and the data has been taken from WDI 2020 (Table 1).

Table 1: Portrayal of Variables

\begin{tabular}{clll}
\hline Code & \multicolumn{1}{c}{ Variable for Evaluation of Country Climate } & \multicolumn{1}{c}{ Measure } & Acceptable Criteria \\
\hline $\mathbf{1}$ & $\begin{array}{l}\text { Exposure to impact -Land area where elevation is below 5 } \\
\text { meters }\end{array}$ & \% of land area \\
$\mathbf{2}$ & $\begin{array}{l}\text { Exposure to impact -Population living in areas where } \\
\text { elevation is below 5 meters }\end{array}$ & \% of total population \\
$\mathbf{3}$ & $\begin{array}{l}\text { Exposure to impact -Population affected by droughts, } \\
\text { floods, and extreme temperatures }\end{array}$ & $\begin{array}{l}\text { Smaller is the best } \\
\text { average annual; \% of } \\
\text { total population }\end{array}$ & Smaller is the best \\
$\mathbf{4}$ & $\begin{array}{l}\text { Exposure to impact -Urban land area where elevation is } \\
\text { below 5 meters }\end{array}$ & \% of urban land area & Smaller is the best \\
$\mathbf{5}$ & $\begin{array}{l}\text { Exposure to impact -Rural population living in areas } \\
\text { where elevation is below 5 meters }\end{array}$ & \% of rural population & Smaller is the best \\
$\mathbf{6}$ & $\begin{array}{l}\text { Exposure to impact -Rural land area where elevation is } \\
\text { below 5 meters }\end{array}$ & \% of rural land area & Smaller is the best \\
$\mathbf{7}$ & $\begin{array}{l}\text { Exposure to impact -Urban population living in areas } \\
\text { where elevation is below 5 meters }\end{array}$ & \% of urban population & Smaller is the best \\
$\mathbf{8}$ & Resilience -Disaster risk reduction progress score & 1, worst to 5,best & Larger is the best \\
\hline
\end{tabular}


Justification for following the aforementioned framework is grounded in literature. Ahmad et al. (2020) and Ngo \& Horton (2016) affirmed that escalating of extreme temperature from climate change may badly affect birth weight, diverge by socioeconomic status and failure to future wheat yield. Fahad and Wang (2020) identified that rainfall changes, drought, frequent floods and temperature rises are the major challenges associated with climate instability that have had a negative effect on the rural area of country's agricultural sector. Sajjad-Ghaffar (2019) conducted a detailed study on climate change and extreme temperature in different provinces of Pakistan and uncovered that projected climate indicates the frequency of summer days on average increase of 6 days in the region of Gilgit Baltistan and Azad Jammu Kashmir (GB-AJK) in next 30 years that causes heavy precipitation in the province of Khyber Pakhtunkhwa (KP). Projected climate further shows an average increase of $1.9{ }^{\circ} \mathrm{C}$ in the mean minimum temperature in the province of Punjab over the past 54 years, an average increase of $1.3{ }^{\circ} \mathrm{C}$ in the mean maximum temperature in the province of KP in the end of year 2045 and an average projected increase of $1.4{ }^{\circ} \mathrm{C}$ in the mean minimum temperature in the province of Sindh over the next 30 years. O'Brien and Leichenko (2000) developed a double exposure framework that entails "winners" or "losers" by change of climate and globalization. The study further argued that urban population is vulnerable to climate change as the result of severe flooding, storms and mudslides. Ju et al. (2019) investigated climate related uncertainties in urban land area where elevation is below 10 meters and stated that median under high Greenhouse Gas (GHG) calculates 0-35\% flood exposed in 2000-2020, which will be increasing to 40-67\% during 2008-2010 and the median under low GHG estimates for the same period are $10 \%$ to $38 \%$ and $20 \%$ to $54 \%$. Fahad and Wang (2018) reported that climate change raises climatic risks perception particularly in rural land area (i.e. agriculture sector) of Khyber Pakhtunkhawa province of Pakistan. Apreda et al. (2019) carried the study in urban population of East Naples, Italy and argued that the proposed model is helpful in monitoring the climatic fluctuation and its possible implications on urban population for local adoptive solutions. Ngin et al. (2020) reported that climate change (disasters, flood \& storms and extreme temperature) affects resilience in tourism and hospitality sectors that requires adaptation of policies to mitigate the risks.

\section{Methodology}

Philosophical approach of the study is quantitative and descriptive. It is a cross sectional deductive quantitative study using secondary data extracted from World Development Indicators (WDI) 2020. The study employs Grey Relational Analysis (GRA) as method of investigation. This methodology has inherent privileges over traditional methodologies. It has the capability to utilize wide variety of data of different units of measurement, volumes and nature, simultaneously in mathematical equations. It is also capable of dealing with multitude of alternatives \& criteria and to compare it with some reference from within the series (Hamzaçebi \& Pekkaya, 2011; Kuo et al., 2008; Tayyar et al., 2014; Wu, 2002). The procedure of employing GRA and the scheme of symbols are adopted from Ertuğrul et al. (2016). GRA has been amplified with classification of countries to provide deeper and informed insights of the results of GRA (Qazi et al. 2020). The analysis, therefore, proceeds stepwise as follows:

Step 1: Created a data set and established decision matrix Eq. (1).

$$
x_{i}(k)=\left[\begin{array}{ccc}
x_{1}(1) x_{1}(2) & \cdots & x_{1}(m) \\
\vdots & \ddots & \vdots \\
x_{n}(1) x_{n}(2) & \cdots & x_{n}(m)
\end{array}\right] \quad \text { Eq. }(1)
$$

Table 2: Climate Data of Countries

\begin{tabular}{|c|c|c|c|c|c|c|c|c|c|}
\hline Sr. & Country & 1 & 2 & 3 & 4 & 5 & 6 & 7 & 8 \\
\hline 1 & Algeria & 0 & 0.8 & 0 & 0 & 0.2 & 0 & 0.6 & 4 \\
\hline 2 & Argentina & 0.9 & 3 & 0.2 & 0.1 & 1 & 0.8 & 2.1 & 3 \\
\hline ... & ............ & $\cdots$ & $\cdots$ & $\cdots$ & $\cdots$ & $\cdots$ & $\cdots$ & $\cdots$ & ... \\
\hline ... & ........... & ... & $\ldots$ & $\ldots$ & $\ldots$ & $\ldots$ & $\ldots$ & $\ldots$ & ... \\
\hline 48 & Pakistan & 1.5 & 1.1 & 1.1 & 0 & 0.4 & 1.5 & 0.6 & 4 \\
\hline
\end{tabular}




\begin{tabular}{llcccccccc}
\hline 49 & Panama & 1.7 & 3 & 0.2 & 0.1 & 1.4 & 1.6 & 1.6 & 3 \\
$\ldots$ & $\ldots \ldots \ldots .$. & $\ldots$ & $\ldots$ & $\ldots$ & $\ldots$ & $\ldots$ & $\ldots$ & $\ldots$ & $\ldots$ \\
$\ldots$. & $\ldots \ldots \ldots .$. & $\ldots$ & $\ldots$ & $\ldots$ & $\ldots$ & $\ldots$ & $\ldots$ & $\ldots$ & $\ldots$ \\
$\mathbf{6 5}$ & Venezuela, RB & 1.5 & 2.5 & 0.2 & 0.1 & 0.7 & 1.4 & 1.8 & 3 \\
$\mathbf{6 6}$ & Yemen, Rep. & 0.4 & 1.6 & 0.1 & 0 & 0.7 & 0.4 & 0.9 & 2 \\
\hline \multicolumn{6}{c}{ Source of Data: [World Development Indicators (WDI), 2020] }
\end{tabular}

Step 2: Created reference series and comparison matrix Eq. (2)

$$
x_{0}=\left[x_{0}(k) \ldots \ldots \ldots \ldots x_{0}(n)\right] \quad E q .(2)
$$

Table 3: Reference Sequence and Comparable Sequences

\begin{tabular}{|c|c|c|c|c|c|c|c|c|c|}
\hline Sr. & Country & 1 & 2 & 3 & 4 & 5 & 6 & 7 & 8 \\
\hline $\mathbf{0}$ & Reference Sequence & 0 & 0 & 0 & 0 & 0 & 0 & 0 & 5 \\
\hline 1 & Algeria & 0 & 0.8 & 0 & 0 & 0.2 & 0 & 0.6 & \\
\hline 2 & Argentina & 0.9 & 3 & 0.2 & 0.1 & 1 & 0.8 & 2.1 & 3 \\
\hline ... & ........... & $\ldots$ & $\cdots$ & $\ldots$ & $\ldots$ & $\ldots$ & $\ldots$ & $\ldots$ & ... \\
\hline ... & ....... & ... & $\ldots$ & $\ldots$ & $\ldots$ & $\ldots$ & $\ldots$ & $\cdots$ & \\
\hline 48 & Pakistan & 1.5 & 1.1 & 1.1 & 0 & 0.4 & 1.5 & 0.6 & 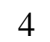 \\
\hline 49 & Panama & 1.7 & 3 & 0.2 & 0.1 & 1.4 & 1.6 & 1.6 & 3 \\
\hline ... & .. & $\ldots$ & $\cdots$ & $\ldots$ & $\ldots$ & $\ldots$ & $\ldots$ & $\ldots$ & $\cdots$ \\
\hline$\ldots$ & 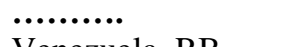 & 15 & & $\cdots$ & $\ldots$ & & $\ldots$ & $\cdots$ & \\
\hline 65 & Ven & 1.5 & 2.5 & 0.2 & 0.1 & 0.7 & 1.4 & 1.8 & 3 \\
\hline 66 & Yemen, Rep. & 0.4 & 1.6 & 0.1 & 0 & 0.7 & 0.4 & 0.9 & 2 \\
\hline
\end{tabular}

Step 3: Created a normalized matrix for larger and smaller acceptable Eq. (3) and Eq. (4)

1- For larger the better

2- For smaller the better

$$
x_{i}^{*}(k)=\frac{x_{i}^{(0)}(k)-\min x_{i}^{(0)}(k)}{\max x_{i}^{(o)}(k)-\min x_{i}^{(o)}(k)} \quad \text { Eq. (3) }
$$

$$
x_{i}(k)=\frac{\max x_{i}^{(o)}(k)-x_{i}^{(0)}(k)}{\max x_{i}^{(0)}(k)-\min x_{i}^{(0)}(k)} \quad \text { Eq. (4) }
$$

\begin{tabular}{|c|c|c|c|c|c|c|c|c|c|}
\hline Sr. & Country & 1 & 2 & 3 & 4 & 5 & 6 & 7 & 8 \\
\hline $\mathbf{0}$ & Reference Sequence & 1.0000 & 1.0000 & 1.0000 & 1.0000 & 1.0000 & 1.0000 & 1.0000 & 1.0000 \\
\hline 1 & Algeria & 1.0000 & 0.9834 & 1.0000 & 1.0000 & 0.9959 & 1.0000 & 0.9496 & 0.7500 \\
\hline 2 & Argentina & 0.9802 & 0.9378 & 0.9773 & 0.9600 & 0.9793 & 0.9824 & 0.8235 & 0.5000 \\
\hline$\ldots$ & .......... & ... & ... & ... & ... & ... & ... & ... & ... \\
\hline$\ldots$ & ........... & $\cdots$ & ... & ... & ... & ... & ... & ... & ... \\
\hline 48 & Pakistan & 0.9670 & 0.9772 & 0.8750 & 1.0000 & 0.9917 & 0.9670 & 0.9496 & 0.7500 \\
\hline 49 & Panama & 0.9626 & 0.9378 & 0.9773 & 0.9600 & 0.9710 & 0.9648 & 0.8655 & 0.5000 \\
\hline$\cdots$ & ........... & $\cdots$ & ... & $\cdots$ & $\cdots$ & $\cdots$ & $\cdots$ & ... & $\cdots$ \\
\hline$\dddot{65}$ & Venezuela RB & $\ddot{0} 670$ & $0 \ddot{9481}$ & $0 \ddot{9773}$ & $0 \ddot{9600}$ & $0 \ddot{9855}$ & 0.9692 & $0 \ddot{8487}$ & $0 . \ddot{5000}$ \\
\hline 66 & Yemen, Rep. & 0.9912 & 0.9668 & 0.9886 & 1.0000 & 0.9855 & 0.9912 & 0.9244 & 0.2500 \\
\hline
\end{tabular}

Table 4: Normalized Comparable Sequences

For example: calculation of Argentina, "Exposure to impact-Land area where elevation is below 5 meters" (1).

$$
x_{2}^{*}(1)=\frac{\max x_{2}^{(0)}(1)-x_{2}^{0}(1)}{\max x_{2}^{0}(1)-\min x_{2}^{o}(1)}=\frac{45.5-0.9}{45.5-0}=0.9802
$$

Step 4: Deviation Sequence calculated Eq. (5) 


$$
\Delta_{0 i}(k)=\left|x_{0}^{*}(k)-x_{i}^{*}(k)\right| \quad E q .(5)
$$

For biggest deviation Eq. (6)

$$
\Delta_{\max }=\max _{\forall j \varepsilon i} \max _{\forall k}\left|x_{0}^{*}(k)-x_{j}^{*}(k)\right| \quad \text { Eq. (6) }
$$

For smallest deviation Eq. (7)

$$
\Delta_{\min }=\min _{\forall j \varepsilon i} \min _{\forall k}\left|x_{0}^{*}(k)-x_{j}^{*}(k)\right| \quad E q . \text { (7) }
$$

\begin{tabular}{|c|c|c|c|c|c|c|c|c|c|}
\hline Sr. & Country & 1 & 2 & 3 & 4 & 5 & 6 & 7 & 8 \\
\hline $\mathbf{0}$ & Reference Sequence & 0.0000 & 0.0000 & 0.0000 & 0.0000 & 0.0000 & 0.0000 & 0.0000 & 0.0000 \\
\hline 1 & Algeria & 0.0000 & 0.0166 & 0.0000 & 0.0000 & 0.0041 & 0.0000 & 0.0504 & 0.2500 \\
\hline 2 & Argentina & 0.0198 & 0.0622 & 0.0227 & 0.0400 & 0.0207 & 0.0176 & 0.1765 & 0.5000 \\
\hline$\cdots$ & …....... & $\cdots$ & $\cdots$ & ... & ... & ... & ... & ... & ... \\
\hline ... & …....... & $\cdots$ & $\cdots$ & & 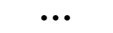 & $\cdots$ & . & 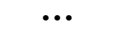 & $\cdots$ \\
\hline 48 & Pakistan & 0.0330 & 0.0228 & 0.1250 & 0.0000 & 0.0083 & 0.0330 & 0.0504 & 0.2500 \\
\hline 49 & Panama & 0.0374 & 0.0622 & 0.0227 & 0.0400 & 0.0290 & 0.0352 & 0.1345 & 0.5000 \\
\hline$\cdots$ & ........... & $\cdots$ & ... & $\cdots$ & $\cdots$ & $\cdots$ & $\cdots$ & $\cdots$ & $\cdots$ \\
\hline$\dddot{65}$ & "........... & $\ddot{0} 330$ & $0 \ddot{0519}$ & $0 \ddot{0} 27$ & $0 \ddot{0400}$ & $\ddot{0} 145$ & $0 \ddot{0308}$ & $0 \ddot{1513}$ & $\ddot{0} 000$ \\
\hline 66 & Yemen, Rep. & 0.0088 & 0.0332 & 0.0114 & 0.0000 & 0.0145 & 0.0088 & 0.0756 & 0.7500 \\
\hline
\end{tabular}

Table 5: Deviation Sequences

For example: calculation of deviation of Argentina for "Exposure to impact-Population living in areas where elevation is below 5 meters" (2)

$$
\Delta_{02}(2)=\left|x_{0}^{*}(2)-x_{2}^{*}(2)\right|=|1-0.9378|=0.0622
$$

Step 5: Grey relational co-efficient is calculated Eq. (8). Term $\xi$ is distinguishing co-efficient between 0

\begin{tabular}{|c|c|c|c|c|c|c|c|c|c|}
\hline Sr. & Country & 1 & 2 & 3 & 4 & 5 & 6 & 7 & 8 \\
\hline $\mathbf{0}$ & Reference Sequence & 1.0000 & 1.0000 & 1.0000 & 1.0000 & 1.0000 & 1.0000 & 1.0000 & 1.0000 \\
\hline 1 & Algeria & 1.0000 & 0.9679 & 1.0000 & 1.0000 & 0.9918 & 1.0000 & 0.9084 & 0.6667 \\
\hline 2 & Argentina & 0.9619 & 0.8893 & 0.9565 & 0.9259 & 0.9602 & 0.9660 & 0.7391 & 0.5000 \\
\hline$\cdots$ & .............. & $\ldots$ & $\cdots$ & $\ldots$ & $\cdots$ & $\cdots$ & $\cdots$ & $\cdots$ & $\ldots$ \\
\hline$\ldots$ & …........... & ... & $\ldots$ & ... & $\ldots$ & ... & ... & ... & ... \\
\hline 48 & Pakistan & 0.9381 & 0.9563 & 0.8000 & 1.0000 & 0.9837 & 0.9381 & 0.9084 & 0.6667 \\
\hline 49 & Panama & 0.9305 & 0.8893 & 0.9565 & 0.9259 & 0.9451 & 0.9343 & 0.7881 & 0.5000 \\
\hline$\ldots$ & ........... & ... & ... & ... & ... & ... & ... & ... & ... \\
\hline$\ldots$ & …........... & $\ldots$ & $\ldots$ & ... & $\ldots$ & ... & ... & ... & $\ldots$ \\
\hline 65 & Venezuela, RB & 0.9381 & 0.9060 & 0.9565 & 0.9259 & 0.9718 & 0.9420 & 0.7677 & 0.5000 \\
\hline 66 & Yemen, Rep. & 0.9827 & 0.9377 & 0.9778 & 1.0000 & 0.9718 & 0.9827 & 0.8686 & 0.4000 \\
\hline
\end{tabular}
and 1 value of which is 0.5 in literature.

$$
\gamma\left[x_{0}^{*}(k), x_{i}^{*}(k)\right]=\frac{\Delta_{\min }+\xi \Delta_{\max }}{x_{0 i}(k)+\xi \Delta_{\max }}, 0<\gamma\left[x_{o}^{*}(k), x_{i}^{*}(k)\right] \leq 1
$$

Table 6: Grey Relational Co-efficient

For example: calculation of Grey Relational Co-efficient of Argentina for "Exposure to impact Population living in areas where elevation is below 5 meters" (2)

$$
\gamma\left[x_{0}^{*}(2), x_{2}^{*}(2)\right]=\frac{\Delta_{\min +\xi} \Delta_{\max }}{\Delta_{2}(2)+\xi \Delta_{\max }}=\frac{0+(0.5) \times 1}{0.0622+(0.5) \times 1}=0.8893
$$


Step 6: Weighted sum of grey relational co-efficient (GRG) is calculated Eq. (9) and Eq. (10).

$$
\begin{array}{ll}
\gamma\left(x_{0}^{*}, x_{i}^{*}\right)=\sum_{k=1}^{n} \beta_{k} \gamma\left[x_{0}^{*}(k), x_{i}^{*}(k)\right] & E q . \text { (9) } \\
\sum_{k=1}^{n} \beta_{k}=1 & \text { Eq. (10) }
\end{array}
$$

\begin{tabular}{|c|c|c|}
\hline Sr. & Country & GRG \\
\hline $\mathbf{0}$ & Reference Sequence & 1.0000 \\
\hline 1 & Algeria & 0.9418 \\
\hline 2 & Argentina & 0.8624 \\
\hline$\cdots$ & …........ & $\cdots$ \\
\hline$\ddot{18}$ & ........... & 08080 \\
\hline 48 & Pakistan & 0.8989 \\
\hline 49 & Panama & 0.8587 \\
\hline$\cdots$ & …........ & $\cdots$ \\
\hline$\ddot{65}$ & Venezuela, RB & $0 . \ddot{8635}$ \\
\hline 66 & Yemen, Rep. & 0.8902 \\
\hline
\end{tabular}

Table 7: Grey Relational Grades (GRG)

For example: GRG for Argentina is calculated as under

$$
\begin{gathered}
\gamma\left(x_{0}^{*}, x_{2}^{*}\right)=\sum_{k=1}^{n} \beta_{k} \gamma\left[x_{0}^{*}(2), x_{2}^{*}(k)\right] \\
=0.125 \times(0.9619+0.8893+0.9565+0.9259+0.9602+0.9660+0.7391+0.5000)=0.8624
\end{gathered}
$$

Since, there is a list of sixty-six countries having different rankings on the continuum of GRGs and it is appropriate to classify into rather rational sub-groupings, therefore, same are classified into much better, better, somewhat better, fair, poor, somewhat worse and worse climate of countries. In fact, we have divided the list of sixty-six countries over the items of scale and made seven assemblages of countries and mentioned the corresponding brackets of GRG of countries Table 8.

Table 8: Classification of Countries

\begin{tabular}{cll}
\hline Sr. & \multicolumn{1}{c}{ Ensign } & \multicolumn{1}{c}{ Description } \\
\hline $\mathbf{1}$ & Much Better & Countries having GRG ranging between 1.00000 to 0.9139 are considered having excellent climate. \\
$\mathbf{2}$ & Better & Countries having GRG ranging between 0.9084 to 0.8989 are considered having very good climate. \\
$\mathbf{3}$ & Somewhat Better & Countries having GRG ranging between 0.8982 to 0.8775 are considered having good climate. \\
$\mathbf{4}$ & Fair & Countries having GRG ranging between 0.8765 to 0.8634 are considered having satisfactory \\
$\mathbf{5}$ & Poor & climate. \\
$\mathbf{6}$ & Somewhat & Countries having GRG ranging between 0.8624 to 0.8299 are considered having poor climate. \\
$\mathbf{7}$ & Worse & Countries having GRG ranging between 0.8221 to 0.7632 are considered having very poor climate. \\
& & Countries having GRG ranging between 0.7626 to 0.5917 are considered having worst climate. \\
\hline
\end{tabular}

Readers will find amplifications of classification significantly helpful in making an informed opinion about a country's climate change.

\section{Results}

It is utmost important to improve understanding of the climate systems for scientists because they want to compare climate of countries and predict that how climate may change over the period of time in future. There is dearth of climate models comparing the country-wise position to predict as how climate of country is relatively better than others and how it may change in the future. Aim of the study is to evaluate and rank countries on the basis of a multitude of variables proxy to climate and investigate Pakistan's climate qua selected sixty-six countries of the world. It follows quantitative research philosophy based on secondary data using GRA. The study provides understanding of 
the climate system to scientists for climate models to predict, test and improve in future. It is a crystalized topic hence there is influx of literature but it can fairly be said that there is really dearth of comparative studies at country levels particularly using composite indices like GRA.

Table 9: Ranking of Sixty-six Countries on Basis of Climate Using GRA

\begin{tabular}{|c|c|c|c|c|c|c|c|c|}
\hline Country & GRG* & Rank & Country & GRG* & Rank & Country & GRG* & Rank \\
\hline Reference Sequence & 1 & 0 & Mexico & 0.8981 & 22 & Ghana & 0.8540 & 45 \\
\hline Much Be & tter & & Honduras & 0.8975 & 23 & Cuba & 0.8536 & 46 \\
\hline Switzerland & 1.0000 & 1 & Nicaragua & 0.8964 & 24 & Malaysia & 0.8451 & 47 \\
\hline Costa Rica & 0.9713 & 2 & Vanuatu & 0.8959 & 25 & Malawi & 0.8417 & 48 \\
\hline Syrian Arab Republic & 0.9445 & 3 & Yemen, Rep. & 0.8902 & 26 & Georgia & 0.8415 & 49 \\
\hline Algeria & 0.9418 & 4 & Dominican Republic & 0.8894 & 27 & Australia & 0.8299 & 50 \\
\hline Brazil & 0.9347 & 5 & Ecuador & 0.8825 & 28 & \multicolumn{3}{|c|}{ Somewhat Worse } \\
\hline Bulgaria & 0.9319 & 6 & Poland & 0.8785 & 29 & Sri Lanka & 0.8221 & 51 \\
\hline North Macedonia & 0.9295 & 7 & Lao PDR & 0.8775 & 30 & Cabo Verde & 0.8202 & 52 \\
\hline Samoa & 0.9266 & 8 & \multicolumn{3}{|c|}{ Fair } & Mozambique & 0.8142 & 53 \\
\hline Chile & 0.9175 & 9 & United States & 0.8765 & 31 & India & 0.8113 & 54 \\
\hline Tanzania & 0.9139 & 10 & Peru & 0.8760 & 32 & Germany & 0.8036 & 55 \\
\hline \multicolumn{3}{|c|}{ Better } & Kenya & 0.8760 & 33 & Indonesia & 0.7940 & 56 \\
\hline Finland & 0.9084 & 11 & New Zealand & 0.8719 & 34 & Jamaica & 0.7856 & 57 \\
\hline Comoros & 0.9079 & 12 & Cote d'Ivoire & 0.8715 & 35 & Italy & 0.7805 & 58 \\
\hline Mauritius & 0.9050 & 13 & Romania & 0.8661 & 36 & Japan & 0.7659 & 59 \\
\hline Morocco & 0.9046 & 14 & Solomon Islands & 0.8657 & 37 & Senegal & 0.7632 & 60 \\
\hline Madagascar & 0.9045 & 15 & Sweden & 0.8656 & 38 & & orse & \\
\hline Nigeria & 0.9037 & 16 & Venezuela, RB & 0.8635 & 39 & Fiji & 0.7626 & 61 \\
\hline Colombia & 0.9032 & 17 & Lebanon & 0.8634 & 40 & Thailand & 0.7070 & 62 \\
\hline El Salvador & 0.9032 & 18 & \multicolumn{3}{|c|}{ Poor } & $\begin{array}{l}\text { Guinea- } \\
\text { Bissau }\end{array}$ & 0.7047 & 63 \\
\hline Guatemala & 0.9026 & 19 & Argentina & 0.8624 & 41 & Bangladesh & 0.6902 & 64 \\
\hline Pakistan & 0.8989 & 20 & Panama & 0.8587 & 42 & $\begin{array}{l}\text { Marshall } \\
\text { Islands }\end{array}$ & 0.6081 & 65 \\
\hline \multicolumn{3}{|c|}{ Somewhat Better } & Sierra Leone & 0.8574 & 43 & Maldives & 0.5917 & 66 \\
\hline Canada & 0.8982 & 21 & Norway & 0.8553 & 44 & & & \\
\hline
\end{tabular}

* Grey Relational Grades

Results show that Switzerland, Costa Rica, Syrian, Arab Republic, Algeria, Brazil, Bulgaria, North Macedonia, Samoa, Chile and Tanzania have much better climate. Most of the countries under this class are Arabian Countries (AC), member countries of European Union (EE), Organization for Economic Cooperation and Development (OECD) and Union of South American Nations (UNASUR). Finland, Comoros, Mauritius, Morocco, Madagascar, Nigeria, Colombia, El Salvador, Guatemala and Pakistan have better climate. Most of that are member countries of Southern Africa Development Community (SADC) and South Asia. Canada, Mexico, Honduras, Nicaragua, Vanuatu, Yemen, Rep., Dominican Republic, Ecuador, Poland and Lao PDR have somewhat better climate. Most of that are member countries of Asia Pacific Economic Cooperation (APEC), Mercado Común Centroamericano (MCCA), North American Free Trade Agreement (NAFTA) and Union of South American Nations (UNASUR). United States, Peru, Kenya, New Zealand, Cote d'Ivoire, Romania, Solomon Islands, Sweden, Venezuela, RB Lebanon have fair climate. Most of which are member countries of APEC and OECD. Argentina, Panama, Sierra Leone, Norway, Ghana, Cuba, Malaysia, Malawi, Georgia, and Australia have poor climate. Most of that are member countries of APEC, Japan \& Asian Pacific Rim (J\&APR), OECD and UNASUR. Sri Lanka, Cabo Verde, Mozambique, India, Germany, Indonesia, Jamaica, Italy, Japan, Senegal have somewhat worse climate. Most of which are member countries of OECD. Fiji, Thailand, Guinea-Bissau, Bangladesh, Marshall, Islands and Maldives have worse climate. Most of that are member countries of South Asian Association for Regional Cooperation (SAARC). Pakistan has comparatively better climate. 


\section{Discussion}

Objectives of the study include evaluation and ranking of 66 countries on the basis of climate with special focus on Pakistan. In fact it aims to rank the countries on the basis of composite indices of grey relational grades. It is different study from contemporary literature in methodology, criteria and alternatives. It also has wider scope and generalizability than other studies. It provides opportunity to the readers to build understanding on the basis of juxtaposed and visualized the country level differences in climate on objective basis and to have rather informed deeper insights. Some of the studies are directly comparable with that of our work. A comparison has therefore been generated presented Table 10.

Table 10: Comparison with Cotemporary Studies

\begin{tabular}{|c|c|c|c|c|}
\hline Studies & Focus & Variables/Factors & Methodology & Results \\
\hline Current & Pakistan & $\begin{array}{l}\text { Exposure to impact-land } \\
\text { area/urban land area/rural land } \\
\text { area where elevation is below } 5 \\
\text { meters, rural population, urban } \\
\text { population, resilience -Disaster } \\
\text { risk reduction, droughts, floods, } \\
\text { and extreme temperatures }\end{array}$ & $\begin{array}{l}\text { Grey relational } \\
\text { analysis }\end{array}$ & $\begin{array}{l}\text { Most of Arabian Countries (AC), } \\
\text { member countries of European } \\
\text { Union (EE), Organization for } \\
\text { Economic Cooperation and } \\
\text { Development (OECD) and Union } \\
\text { of South American Nations } \\
\text { (UNASUR) have much better } \\
\text { climate. Most of Southern Africa } \\
\text { Development Community (SADC) } \\
\text { and South Asia countries have } \\
\text { better climate. }\end{array}$ \\
\hline $\begin{array}{l}\text { Ngin et al. } \\
(2020)\end{array}$ & $\begin{array}{l}\text { How climate } \\
\text { change impacts } \\
\text { and climate } \\
\text { resilience of } \\
\text { micro businesses }\end{array}$ & $\begin{array}{l}\text { Climate change, natural disaster } \\
\text { (pre-disaster preparedness, } \\
\text { response, recovery), business }\end{array}$ & $\begin{array}{l}\text { Interviews } \\
\text { summarized } \\
\text { into themes and } \\
\text { categories } \\
\text { based on } \\
\text { emerging data } \\
\text { patterns }\end{array}$ & $\begin{array}{l}\text { Climate change impacts and } \\
\text { disaster resilience in tourism and } \\
\text { hospitality sectors require } \\
\text { adaptation policies \& measures to } \\
\text { be location \& time bounded to } \\
\text { mitigate the disaster risk. }\end{array}$ \\
\hline $\begin{array}{l}\text { Ju et al. } \\
(2019)\end{array}$ & $\begin{array}{l}\text { Climate related } \\
\text { uncertainties in } \\
\text { urban land area } \\
\text { having elevation } \\
\text { below ten meters }\end{array}$ & Fourteen data sets & $\begin{array}{l}\text { Three } \\
\text { dimensional } \\
\text { (3Di) } \\
\text { hydrodynamic } \\
\text { model }\end{array}$ & $\begin{array}{l}\text { Investigated climate related } \\
\text { uncertainties in urban land area } \\
\text { where elevation is below } 10 \text { meters } \\
\text { and stated that median under high } \\
\text { Greenhouse Gas (GHG) calculates } \\
0-35 \% \text { flood exposed in } 2000 \\
2020 \text {, which will be increasing to } \\
40-67 \% \text { during } 2080-2100 \text { and the } \\
\text { median under low GHG estimates } \\
\text { for the same period are } 10 \% \text { to } \\
38 \% \text { and } 20 \% \text { to } 54 \%\end{array}$ \\
\hline
\end{tabular}

The results of study are aligned with contemporary literature in general and with Busby et al. (2018) in particular.

\section{Conclusion}

Climate of the country has direct significant effect on day-to-day activities of business community. There is dearth of climate models comparing the country-wise position to predict as how climate of country is relatively better than others and how may change in the future. This study follows quantitative research philosophy 
based on secondary data. Grey Relational Analysis (GRA) is used as a technique of investigation. Results show that most of Arabian Countries (AC), member countries of European Union (EE), Organization for Economic Cooperation and Development (OECD) and Union of South American Nations (UNASUR) have much better climate. Most of Southern Africa Development Community (SADC) and South Asia countries have better climate. Most of Asia Pacific Economic Cooperation (APEC), Mercado Común Centroamericano (MCCA), North American Free Trade Agreement (NAFTA) and Union of South American Nations (UNASUR) have somewhat better climate. Most of member countries of APEC and OECD have fair climate. Most of member countries of APEC, Japan \& Asian Pacific Rim (J\&APR), OECD and UNASUR have poor climate. Some of member countries of OECD have somewhat worse climate. Most of member countries of South Asian Association for Regional Cooperation (SAARC) have worse climate. Pakistan has comparatively better climate. This study contributes to existing theories for a deep understanding of the phenomenon. Scientifically develop GRA hierarchy-based system is a significant contribution to literature. The study quantitatively examined the phenomena by providing more supplementary information. It provides an important input for further studies. It is ever first study using GRA method which established relationships among variables and calculated correlation co-efficient with acceptable series. Empirical evidence presented in this study provides novel insights into relationship of variables by way of hierarchically organized but not oversimplified model. Findings constitute a solid basis designing of future quantitative studies. It has significant relevance political governments, researchers, policy makers and scientists. Policy setting to respond to predicted changes. This study has certain limitation as well. Firstly, cross sectional study in future studies may be longitudinal using time series/panel data. Secondly, this study uses GRA the hierarchical technique there are other hierarchical techniques as well e.g. RIDIT, AHP, TOPSIS, SWARA, VIKOR, ISM future studies may use these methodologies. Thirdly, we have given equal weight to all variables it may be changed on some other basis say on the basis's expert opinion etc. it is considered that different weights specific to the system can be selected for Grey Relational Analysis using Multi Criteria Decision Making Methods (MCDMs).

\section{References}

Abid, M., Scheffran, J., Schneider, U. A., \& Elahi, E. (2019). Farmer perceptions of climate change, observed trends and adaptation of agriculture in Pakistan. Environmental management, 63(1), 110123.

Abid, M., Schilling, J., Scheffran, J., \& Zulfiqar, F. (2016). Climate change vulnerability, adaptation and risk perceptions at farm level in Punjab, Pakistan. Science of the Total Environment, 547, 447-460.

Ahmad, M. J., Iqbal, M. A., \& Choi, K. S. (2020). Climate-driven constraints in sustaining future wheat yield and water productivity. Agricultural Water Management, 231, 105991.

Ahmed, A., Devadason, E. S., \& Al-Amin, A. Q. (2016). Implications of climate change damage for agriculture: sectoral evidence from Pakistan. Environmental Science and Pollution Research, 23(20), 20688-20699.

Ali, A., \& Erenstein, O. (2017). Assessing farmer use of climate change adaptation practices and impacts on food security and poverty in Pakistan. Climate Risk Management, 16, 183-194.

Amin, A., Nasim, W., Mubeen, M., Sarwar, S., Urich, P., Ahmad, A., ... \& Ali, Q. S. (2018). Regional climate assessment of precipitation and temperature in Southern Punjab (Pakistan) using SimCLIM climate model for different temporal scales. Theoretical and Applied climatology, 131(1), 121-131.

Apreda, C., D’Ambrosio, V., \& Di Martino, F. (2019). A climate vulnerability and impact assessment model for complex urban systems. Environmental Science \& Policy, 93, 11-26.

Aslam, A. Q., Ahmad, I., Ahmad, S. R., Hussain, Y., Hussain, M. S., Shamshad, J., \& Zaidi, S. J. A. (2018). Integrated climate change risk assessment and evaluation of adaptation perspective in southern Punjab, Pakistan. Science of the Total Environment, 628, 1422-1436.

Baarsch, F., Granadillos, J. R., Hare, W., Knaus, M., Krapp, M., Schaeffer, M., \& Lotze-Campen, H. (2020). The impact of climate change on incomes and convergence in Africa. World Development, 126, 104699.

Batool, S., \& Saeed, F. (2018). Unpacking climate impacts and vulnerabilities of cotton farmers in 
Pakistan: a Case study of two semi-arid districts. Earth Systems and Environment, 2(3), 499-514.

Busby, J., Smith, T. G., Krishnan, N., Wight, C., \& Vallejo-Gutierrez, S. (2018). In harm's way: Climate security vulnerability in Asia. World Development, 112, 88-118.

de Vries, W., Posch, M., Simpson, D., \& Reinds, G. J. (2017). Modelling long-term impacts of changes in climate, nitrogen deposition and ozone exposure on carbon sequestration of European forest ecosystems. Science of the Total Environment, 605, 1097-1116.

Ertuğrul, İ., Öztaş, T., Özçil, A., \& Öztaş, G. Z. (2016). Grey relational analysis approach in academic performance comparison of university a case study of Turkish universities. European Scientific Journal, Special Edition, 128-139.

Fahad, S., \& Wang, J. (2018). Farmers' risk perception, vulnerability, and adaptation to climate change in rural Pakistan. Land use policy, 79, 301-309.

Fahad, S., \& Wang, J. (2020). Climate change, vulnerability, and its impacts in rural Pakistan: A review. Environmental Science and Pollution Research, 27(2), 1334-1338.

Fahad, S., Inayat, T., Wang, J., Dong, L., Hu, G., Khan, S., \& Khan, A. (2020). Farmers' awareness level and their perceptions of climate change: A case of Khyber Pakhtunkhwa province, Pakistan. Land Use Policy, 96, 104669.

Hamzaçebi, C., \& Pekkaya, M. (2011). Determining of stock investments with grey relational analysis. Expert Systems with Applications, 38(8), 9186-9195.

Hedlund, J., Fick, S., Carlsen, H., \& Benzie, M. (2018). Quantifying transnational climate impact exposure: New perspectives on the global distribution of climate risk. Global environmental change, 52, 75-85.

Hori, S., \& Syugyo, S. (2020). The function of international business frameworks for governing companies' climate change-related actions toward the 2050 goals. International Environmental Agreements: Politics, Law and Economics, 1-17.

Hussain, M., Liu, G., Yousaf, B., Ahmed, R., Uzma, F., Ali, M. U., ... \& Butt, A. R. (2018). Regional and sectoral assessment on climate-change in Pakistan: social norms and indigenous perceptions on climate-change adaptation and mitigation in relation to global context. Journal of Cleaner Production, 200, 791-808.

Javid, K., Akram, M. A. N., Mumtaz, M., \& Siddiqui, R. (2019). Modeling and mapping of climatic classification of Pakistan by using remote sensing climate compound index (2000 to 2018). Applied Water Science, 9(7), 1-9.

Ju, Y., Lindbergh, S., He, Y., \& Radke, J. D. (2019). Climate-related uncertainties in urban exposure to sea level rise and storm surge flooding: a multi-temporal and multi-scenario analysis. Cities, 92, 230246.

Khan, M. A., Khan, J. A., Ali, Z., Ahmad, I., \& Ahmad, M. N. (2016). The challenge of climate change and policy response in Pakistan. Environmental Earth Sciences, 75(5), 412.

Kim, D., \& Lee, J. (2020). Spatial Changes in Work Capacity for Occupations Vulnerable to Heat Stress: Potential Regional Impacts From Global Climate Change. Safety and health at work, 11(1), $1-9$.

Klymasz-Swartz, A. K., Allen, G. J., Treberg, J. R., Yoon, G. R., Tripp, A., Quijada-Rodriguez, A. R., \& Weihrauch, D. (2019). Impact of climate change on the American lobster (Homarus americanus): Physiological responses to combined exposure of elevated temperature and $\mathrm{pCO}$. Comparative Biochemistry and Physiology Part A: Molecular \& Integrative Physiology, 235, 202-210.

Kuo, Y., Yang, T., \& Huang, G. W. (2008). The use of grey relational analysis in solving multiple attribute decision-making problems. Computers \& industrial engineering, 55(1), 80-93.

Lawrence, J., Blackett, P., \& Cradock-Henry, N. A. (2020). Cascading climate change impacts and implications. Climate Risk Management, 29, 100234.

Liverpool-Tasie, L. S., Pummel, H., Tambo, J. A., Olabisi, L. S., \& Osuntade, O. (2020). Perceptions and exposure to climate events along agricultural value chains: Evidence from Nigeria. Journal of environmental management, 264, 110430.

Malik, S. M., Awan, H., \& Khan, N. (2012). Mapping vulnerability to climate change and its repercussions on human health in Pakistan. Globalization and health, 8(1), 31. 
Nasim, W., Amin, A., Fahad, S., Awais, M., Khan, N., Mubeen, M., ... \& Jamal, Y. (2018). Future risk assessment by estimating historical heat wave trends with projected heat accumulation using SimCLIM climate model in Pakistan. Atmospheric Research, 205, 118-133.

Ngin, C., Chhom, C., \& Neef, A. (2020). Climate change impacts and disaster resilience among micro businesses in the tourism and hospitality sector: The case of Kratie, Cambodia. Environmental research, 186, 109557.

Ngo, N. S., \& Horton, R. M. (2016). Climate change and fetal health: The impacts of exposure to extreme temperatures in New York City. Environmental research, 144, 158-164.

O'Brien, K. L., \& Leichenko, R. M. (2000). Double exposure: assessing the impacts of climate change within the context of economic globalization. Global environmental change, 10(3), 221-232.

Qazi, T. F.,Basit, A.,Asghar, W.\& Niazi, A. A. K.(2020).Composite Appraisal of Women Development in Selected Thirty-six Countries with Special Focus on Pakistan: Applying Grey Incidence Analysis Model. Journal of Businessand Social Review in Emerging Economies, 6(4), 1227-1236.

Saeed, F., \& Athar, H. (2018). Assessment of simulated and projected climate change in Pakistan using IPCC AR4-based AOGCMs. Theoretical and Applied Climatology, 134(3), 967-980.

Sajjad, H., \& Ghaffar, A. (2019). Observed, simulated and projected extreme climate indices over Pakistan in changing climate. Theoretical and Applied Climatology, 137(1), 255-281.

Salik, K. M., Jahangir, S., \& ul Hasson, S. (2015). Climate change vulnerability and adaptation options for the coastal communities of Pakistan. Ocean \& Coastal Management, 112, 61-73.

Shahzad, M. F., \& Abdulai, A. (2020). Adaptation to extreme weather conditions and farm performance in rural Pakistan. Agricultural Systems, 180, 102772.

Singh, G. G., Hilmi, N., Bernhardt, J. R., Cisneros Montemayor, A. M., Cashion, M., Ota, Y., ... \& González- Espinosa, P. C. (2019). Climate impacts on the ocean are making the Sustainable Development Goals a moving target travelling away from us. People and Nature, 1(3), 317-330.

Tayyar, N., Akcanlı, F., Genç, E., \& Erem, I. (2014). Evaluating the financial performance of companies operating in the field of informatics and technology registered in BIST by analytical hierarchy process (AHP) and gray relational analysis (TIA) method. Accounting and Finance Journal, 61, $19-40$.

Uchiyama, C., Stevenson, L. A., \& Tandoko, E. (2020). Climate change research in Asia: A knowledge synthesis of Asia-Pacific Network for Global Change Research (2013-2018). Environmental Research, 188, 109635.

Ullah, H., Rashid, A., Liu, G., \& Hussain, M. (2018). Perceptions of mountainous people on climate change, livelihood practices and climatic shocks: A case study of Swat District, Pakistan. Urban climate, 26, 244-257.

World Development Indicators. (2020). Retrieved April 15, 2020, from http://wdi.worldbank.org/tables.

Wu, H. H. (2002). A comparative study of using grey relational analysis in multiple attribute decision making problems. Quality Engineering, 15(2), 209-217. 